\title{
Polyphyletic Origin of Ornamental Goldfish
}

\author{
Aleksandr V. Podlesnykh1, Vladimir A. Brykov ${ }^{1,2}$, Lubov A. Skurikhina1 \\ ${ }^{1}$ Far Eastern Branch of the Russian Academy of Sciences, A. V. Zhirmunsky Institute of Marine Biology, \\ Vladivostok, Russia \\ ${ }^{2}$ School of Natural Sciences, Far Eastern Federal University, Vladivostok, Russia \\ Email: podlesnykh9@yandex.ru
}

Received 6 May 2015; accepted 17 August 2015; published 20 August 2015

Copyright (C) 2015 by authors and Scientific Research Publishing Inc.

This work is licensed under the Creative Commons Attribution International License (CC BY).

http://creativecommons.org/licenses/by/4.0/

c) (i) Open Access

\begin{abstract}
Mitochondrial DNA fragment of cytb was compared in all species Carassius auratus complex and three forms of ornamental goldfish. It is shown that the phylogenetic relationships between complex species correspond to the existing views, based on mtDNA data and geographical distribution. All forms of ornamental goldfish have a monophyletic origin from Chinese goldfish $C$. auratus auratus. The analysis showed that three nuclear genes ( $r p s 7, G H 1$ and $R h)$ in the two forms of ornamental goldfish (Oriental twintail goldfish and Chinese Ranchu) were almost identical $C$. auratus auratus genes, while all three gene in another more simple form of goldfish (common goldfish) were highly homologous to carp Cyprinus carpio nuclear genes. The obtained data suggested that in the history of aquarium goldfish breeding occurred the stage of distant hybridization between goldfish and common carp. Subsequently, the nuclear genomes of some ornamental forms could be enriched by goldfish genes (a relatively recent form as Oriental twintail goldfish and Chinese Ranchu) or common carp genes (the simplest and most ancient forms like common goldfish) as a result of multidirectional breeding and selection of aquarium goldfish various forms.
\end{abstract}

\section{Keywords}

Goldfish, Common Carp, Distant Hybridization, mtDNA and Nuclear Genes

\section{Introduction}

The ornamental goldfish (Carassius auratus auratus) is the best known species in the history of fish selective breeding and aquaculture and also used as an object of laboratory-based research [1] [2]. Goldfish belongs to the order Cypriniformes and is considered a variant of the wild form of the Chinese silver crucian carp (C. a. auratus) [1]-[3]. The species is native to rivers and lakes of Eurasia, having the center of origin and distribution in China [4] [5]. 
Under natural conditions, Chinese silver crucian carp (C. a. auratus) can change color of its body from grey to yellow or red, and thus it is considered the original form of Chinese goldfish [3] [6]. The body color variations in Chinese silver crucian carp were noted as long ago as at the Tsin (Jin) dynasty (265-420 A.D.). The domesticated goldfish is believed to have appeared during the Song dynasty (approximately 960-1279 A.D.) as a result of artificial selection of individuals with mutations that determine color variations [3] [6] [7]. Goldfish was brought to Japan at the turn of 1500 A.D. and to Europe nearly in 1700 A.D. [3] [7] [8]. Currently, a broad variety of goldfish phenotypes are cultivated: from the simplest morphs (least changed and ancient) to more complicated and recently originated, such as those with spine aberrations, lacking dorsal fin, duplications, and larger other fins.

Until quite recently, the evolutionary origin of ornamental goldfish remained unclear, and the question on its wild ancestors has been raised. The taxonomy of the genus Carassius from East Asia looks intricate due to discrepancies between scientific and common names, and thus there are different points of view on the evolutionary origin of goldfish. The goldfish C. a. auratus (C. auratus as synonym) is usually confused with the crucian carp Carassius carassius (L.), silver crucian carp C. a. gibelio (Bloch) (C. gibelio as synonym), and even with the common carp, Cyprinus carpio (L.) [1]. The available phylogenetic reconstructions, based on comparisons of a major portion of mitochondrial genome (mtDNA), showed that various phenotypes of goldfish may originate from one of the two groups of Chinese silver crucian carp, C. a. auratus or C. a. gibelio [7]. In another study of the phylogeny of ornamental goldfish C. $a$. auratus, based on mitochondrial cytochrome b (cyt b) gene sequence, it was shown that various phenotypes of goldfish from China, Japan, and Europe formed a single monophyletic line that proved the single domestication event in the history of its origin [2]. The study of the evolutionary history of goldfish by using mitochondrial markers cyt $b$ and control region (CR) showed the monophyletic origin of goldfish from a native South China one, $C$. a. auratus, which inhabited the lower course of the Yangtze River [8].

The aim of this work was to study the genealogy of the $C$. auratus complex by using the molecular markers of mitochondrial and nuclear DNA (nDNA); the analysis included various morphotypes of ornamental goldfishes. During our screening studies of nDNA fragments in goldfish, the fact of probable hybridization in the history of origin of some ornamental goldfish forms has been found. Thus, the polyphyletic origin of aquarium goldfish should not be ruled out that calls into question the relevance of their use as model objects for laboratory-based research.

\section{Materials and Methods}

\subsection{Sample Collection}

The individuals of aquarium goldfish, according to http://www.bristol-aquarists.org.uk, belonged to the lines of Oriental twintail goldfish, Chinese Ranchu and common goldfish (Figure 2) were bought from a local ornamental fish dealer. When analyzing the common goldfish one year old immature and one has attained 4 years old female were used. The total DNA of C. a. gibelio, C. carassius and Cyprinus carpio were took from the DNA collection of the A. V. Zhirmunsky Institute of Marine Biology FEB RAS. In comparative studies 23 own gene sequence cytb (mtDNA) and 12 sequences from the GenBank NCBI database were used.

In eight species of C. a. auratus (including ornamental goldfish), C. a. gibelio, C. carassius and Cyprinus carpio we analysed the fragments of gene sequences of nuclear DNA (nDNA): the 1st intron of ribosomal protein S7 (rps7), growth hormone gene $1(G H 1)$ and the rhodopsin gene $(R h)$, a total of 24 sequences. The number and origin sequences are shown in the table (Table).

\subsection{DNA Isolation, PCR Amplification, Cloning and Sequencing}

DNA was isolated from the heart and fins tissues fixed in 96\% ethanol [9]. For amplification of cytb gene sequences of mtDNA primer pair FishcytB-F and THR-Fish-R was used [10]. For sequencing of the nDNA genes was used the following primer pairs: for rps7: S7RPEX1F and S7RPEX2R [11], for GH1 gene Cypr-GH1-1F 5'-AAAATGATTAACGACTTTG-3' and Cypr-GH1-2R 5'-CAAGTAGAAGTCCTCAAAA-3', for rhodopsin $545 \mathrm{Rh}$ and $\mathrm{Rh1039r}$ [12]. GH1 gene sequences consisted of 3, 4 and 5 exons and 3, 4 introns.

PCR was performed in a total volume of $12.5 \mu \mathrm{L}$, containing $10 \times$ PCR buffer $(75 \mathrm{mM}$ Tris $\mathrm{HCl}(\mathrm{pH} 8.8$ at $\left.25^{\circ} \mathrm{C}\right), 20 \mathrm{mM}\left(\mathrm{NH}_{4}\right)_{2} \mathrm{SO}_{4} ; 0.01 \%$ Tween 20 and $\left.1.5 \mathrm{mM} \mathrm{MgCl}_{2}\right) ; 1 \mathrm{mM}$ of dNTP mixture $(0.25 \mathrm{mM}$ each); 0.25 
Table. The location and NCBI number of samples for the C. auratus-complex, C. carassius and Cyprinus carpio examined in the present study.

\begin{tabular}{|c|c|c|c|c|c|}
\hline $\begin{array}{l}\text { English name } \\
\text { Scientific name }\end{array}$ & Location & $\begin{array}{l}\text { Accession no. } \\
\quad(\text { cyt } b)\end{array}$ & \multicolumn{3}{|c|}{ Accession no. (rps7, GH1, Rh) } \\
\hline Gold crucian carp, goldfish & China: Nanking, Yangtze & $\begin{array}{l}\text { EU663597 } \\
\text { EU663598 }\end{array}$ & & & \\
\hline \multirow[t]{3}{*}{ Carassius auratus auratus } & China: Hunan, Dongting water system & $\begin{array}{l}\text { GU086395 } \\
\text { GU086396 }\end{array}$ & & & \\
\hline & Czech Republic & $\begin{array}{c}\text { FJ169952 } \\
\text { EU663574 } \\
\text { EU663584 }\end{array}$ & & & \\
\hline & Russia: Vladivostok & $\begin{array}{c}\text { JF694778 } \\
\text { JF694779 } \\
\text { KM015475* } \\
\text { KM015476* }\end{array}$ & $\begin{array}{l}\text { KM015461* } \\
\text { KM015462* } \\
\text { KM015465* } \\
\text { KM015466 }\end{array}$ & $\begin{array}{l}\text { KM015469* } \\
\text { KM015470* } \\
\text { KM015473* } \\
\text { KM015474* }\end{array}$ & $\begin{array}{l}\text { KM015479* } \\
\text { KM015480 } \\
\text { KM015483* } \\
\text { KM015484 }\end{array}$ \\
\hline $\begin{array}{l}\text { Silver crucian carp, } \\
\text { Silver prussian carp }\end{array}$ & $\begin{array}{l}\text { Russia: Far East, Primorye, } \\
\text { Rasdolnaya River }\end{array}$ & $\begin{array}{l}\text { JQ898590* }^{*} \\
\text { JQ898599* }^{*} \\
\text { JQ898581* }^{*} \\
\text { JQ89596 }^{*}\end{array}$ & $\begin{array}{l}\text { KM015459* } \\
\text { KM015460* }\end{array}$ & $\begin{array}{l}\text { KM015467* } \\
\text { KM015468* }\end{array}$ & $\begin{array}{l}\text { KM015477* } \\
\text { KM015478* }\end{array}$ \\
\hline \multirow[t]{6}{*}{ Carassius gibelio } & Croatia: Danube River Basin, Kupa River & $\begin{array}{l}\text { JQ905033* } \\
\text { JQ905035* }\end{array}$ & & & \\
\hline & Russia: Far East, Amur River & $\begin{array}{l}\text { JQ898585* } \\
\text { JQ898589* }\end{array}$ & & & \\
\hline & Russia: Far East, Primorye, Hanka Lake & $\begin{array}{l}\text { JQ898601* } \\
\text { JQ898603* }\end{array}$ & & & \\
\hline & China: Yantai & FJ822048 & & & \\
\hline & $\begin{array}{l}\text { Russia: Far East, Sea of Japan, Peter } \\
\text { the Great Gulf, Bolshoi Pelis island }\end{array}$ & $\begin{array}{l}\text { JQ898617* } \\
\text { JQ898618* }\end{array}$ & & & \\
\hline & $\begin{array}{c}\text { Russia: Far East, Kamchatka Peninsula, } \\
\text { Kamchatka River }\end{array}$ & $\begin{array}{l}\text { JQ898611* } \\
\text { JQ898612 }^{*}\end{array}$ & & & \\
\hline Japanese silver crucian carp & Japan: Lake Abashiri, Hokkaido & DQ399920 & & & \\
\hline Carassius auratus langsdorfii & Czech Republic: Chrudimka, Elbe basin & DQ399932 & & & \\
\hline \multirow[t]{2}{*}{ Carassius cuvieri } & Japan & AB045144 & & & \\
\hline & $\begin{array}{l}\text { Japan: Tome Miyagi, Hasama, Iijima, } \\
\text { Moguri Pumping Site }\end{array}$ & FJ822043 & & & \\
\hline Crucian carp & Russia: Volga River basin & FJ478014 & KM015463* & KM015471* & KM015481* \\
\hline Carassius carassius & $\begin{array}{l}\text { Germany: pond near Plon, } \\
\text { Schwentine basin }\end{array}$ & DQ399919 & & & \\
\hline \multicolumn{6}{|l|}{ Common carp and carp “koi” } \\
\hline Cyprinus carpio "Koi” & unknown & KJ511882 & & & \\
\hline Cyprinus carpio & Russia: Far East, Amur River & $\begin{array}{l}\text { FJ478020 } \\
\text { FJ478021 }\end{array}$ & KM015464* & $\mathrm{KM} 015472^{*}$ & KM015482* $^{*}$ \\
\hline
\end{tabular}

\footnotetext{
*This study.
}

mM each primer; 10 ng DNA, and 1 unit of Taq DNA polymerase. The reaction conditions included 3 min at $94^{\circ} \mathrm{C}$, followed by 30 cycles of $94^{\circ} \mathrm{C}$ for $30 \mathrm{~s}$; primer annealing for $30 \mathrm{~s}\left(r p s 7,60^{\circ} \mathrm{C} ; G H 1,48^{\circ} \mathrm{C} ; R h, 54^{\circ} \mathrm{C}\right.$ and $c y t b, 57^{\circ} \mathrm{C}$ ); $72^{\circ} \mathrm{C}$ for $1 \mathrm{~min} 30 \mathrm{~s}$; and final extension for $5 \mathrm{~min}$ at $68^{\circ} \mathrm{C}$. The sizes of the PCR products were determined in $1 \%$ agarose gel. Purified gene fragments of nDNA were cloned into plasmid pTZ57R/T, using InsTAclone ${ }^{\mathrm{TM}}$ PCR Cloning Kit (MBI Fermentas). 
From 4 to 7 positive clones of each specimen were selected and analyzed. Plasmid DNA was used as matrices for PCR reaction and then sequencing with the primers M13F and M13R. Purified nucleotide sequences of the nDNA and mtDNA genes were subjected to direct sequencing in both directions using the ABI Prism 3130 Genetic Analyzer and the Big Dye Terminator v. 3.1 Cycle Sequencing Kit standard protocol (Applied Biosystems). Sequences were aligned using the SeqScape v. 2.5 software program (Applied Biosystems). The $r p s 7, G H 1, R h$ and $c y t b$ gene fragments obtained were submitted to the GenBank NCBI (Table).

\subsection{Molecular Data Analyses}

The nucleotide sequences of rps7 and GH1 genes were aligned in UGENEv1.13.1 [13] using MAFFT, and the sequences of genes $c y t b$ and $R h$ aligned using Clustal W algorithm in MEGA5 [14]. Matrix length for cytb after alignment was 797 bp and included 196 variable and 179 parsimony-informative sites. Fragments of the all three nuclear genes were combined. The final matrix combined nucleotide sequences of nDNA with gaps and missing data was 2474 bp and contained 445 variable and 295 potentially parsimony-informative sites.

Phylogenetic trees for sequences of nDNA and mtDNA genomes were constructed using the methods of maximum likelihood (ML) in PAUP 4.0b10 [15] and Bayesian analysis (BA) in Mr. Bayes v. 3.1.2 [16]. Optimal models of nucleotide substitution for the ML and BI tests were calculated in jModelTest [17]. The following models HKY + I + G for combined nDNA data and TrN + G for cytb were selected under the ML test and AIC.

The ML trees were generated in the PAUP v. 40b10 by running 1000 bootstrap replicates with a heuristic search using 100 random addition sequences and TBR algorithm for branch swapping. The model HKY85 + I was used for the Bayesian trees (BA) reconstruction and posterior probabilities (PP) calculation with the MCMC parameters: $2 \times 10^{6}$ generations, sampling every 100 generations and 18,000 selected trees. To calculate the intergroup and intragroup divergence in the analysis of phylogenetic trees topologies pairwise uncorrected $p$-distances were used [14].

\section{Results}

\subsection{Phylogenetic Analysis Based on mtDNA Data}

A phylogenetic analysis of the mitochondrial marker cyt $b$ with the length of 797 bp by using the ML and BI methods revealed clusters of similar topology. The analysis of topologies showed that the clades formed from representatives of the $C$. auratus complex, as well as the ones formed by crucian carp C. carassius and the one of common carp Cyprinus carpio with the carp "Koi” (external group), are in fact monophyletic groups with the high degree of support of branch (Figure 1). The clades in the phylogenetic tree correspond to taxonomic notions that are based upon distribution and validity of representatives of the C. auratus complex and the entire genus Carassius.

The crucian carp C. carassius forms an individual clade, in which the level of divergence $(p)$ from the other representatives of the $C$. auratus complex constitutes $8.5 \%-10 \%$ nucleotide substitutions. The magnitude of genetic differences of the endemic Japanese silver crucian carps C. a. langsdorfii and C. $a$. cuvieri between each other and representatives of the $C$. auratus complex reaches 7.5\% - 8\% base substitutions. The lines of goldfish C. a. auratus and silver crucian carp C. gibelio (phylogenetic group A) represent sister clades with the divergence level $p=2.0 \% \pm 0.5 \%$. Silver crucian carps from Europe, Russian Far East, and China are combined in the clade C. gibelio (A). Individuals of silver crucian carp, which forms the clade (B) in C. gibelio, were earlier referred to the second phylogroup C. gibelio [18] [19], for which the magnitude of genetic differences from the lines C. a. auratus and C. gibelio (A) constitutes 4.4\% - 5.5\% base substitutions. The cluster C. a. auratus comprised, along with native silver crucian carps, all the studied morphological variant of ornamental goldfish that confirms their close genetic relationship. The level of divergence from the external group, consisting of native carps Cyprinus carpio and the "Koi” carp, and the clades that combine representatives of the genus Carassius reached $13 \%-15 \%$.

\subsection{Phylogenetic Analysis Based on nDNA Data}

The phylogenetic analysis of combined fragments of nDNA with the length of 2474 bp, based on ML and BI methods, reveals congruent dendrograms. The colored images of fishes in the combined ML tree of nDNA correspond to the numbers of individuals by cyt $b$ from the database GenBank/NCBI (Table). In the phylogram 


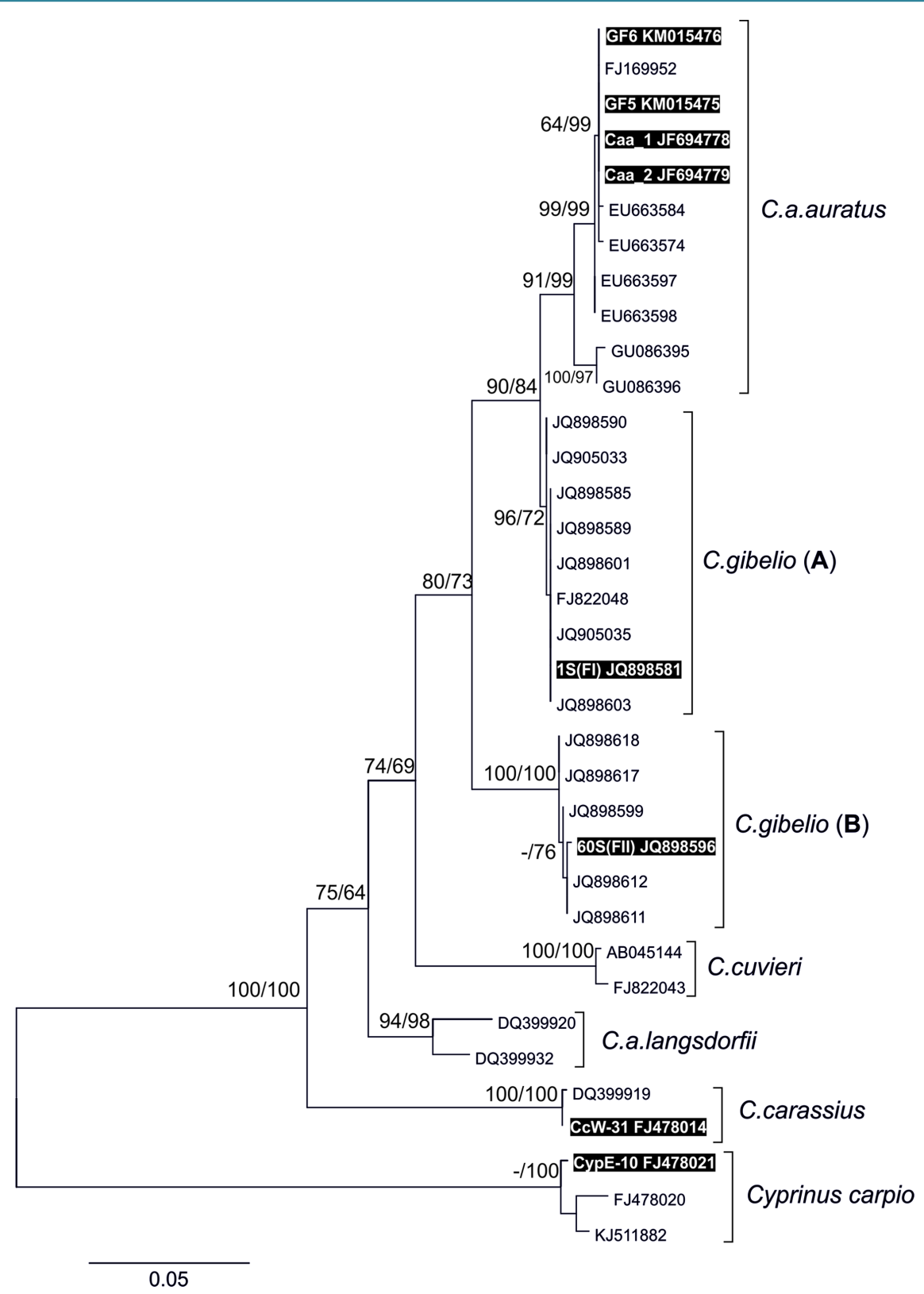

Figure 1. Consensus ML tree demonstrating matrilineal genealogy of the Carassius auratus complex and C. carassius generated from 797 bp cytochrome b sequences (mtDNA). Numbers at the nodes of the branches represent bootstrap support values from 1000 pseudoreplicates and posterior probabilities (PP, \%) from a consensus of 18,000 trees, for ML and BI trees, respectively. Cyprinus carpio is outgroup. Black circled numbers also the same as in Figure 2.

based on mtDNA sequences, the numbers of the same fish specimens are highlighted in dark (Figure 1).

The differences in clustering of certain goldfish individuals were found by comparing the mtDNA and nDNA phylograms. The individuals with phenotypes of ornamental goldfish, which were defined by us as common goldfish and externally differed from probable ancestral forms only in body color variations, proved to be combined with the carp Cyprinus carpio in the nDNA phylogram (Figure 2). At the same time, when analyzing clones in libraries of DNA fragments in these fishes, we did not found the allele variants of nuclear genes, which are appropriate for other ornamental C. a. auratus, silver crucian carp C. gibelio, or crucian carp C. carassius. The lack of both visible and vestigial characters of common carp (barbels around mouth), as well as the body 


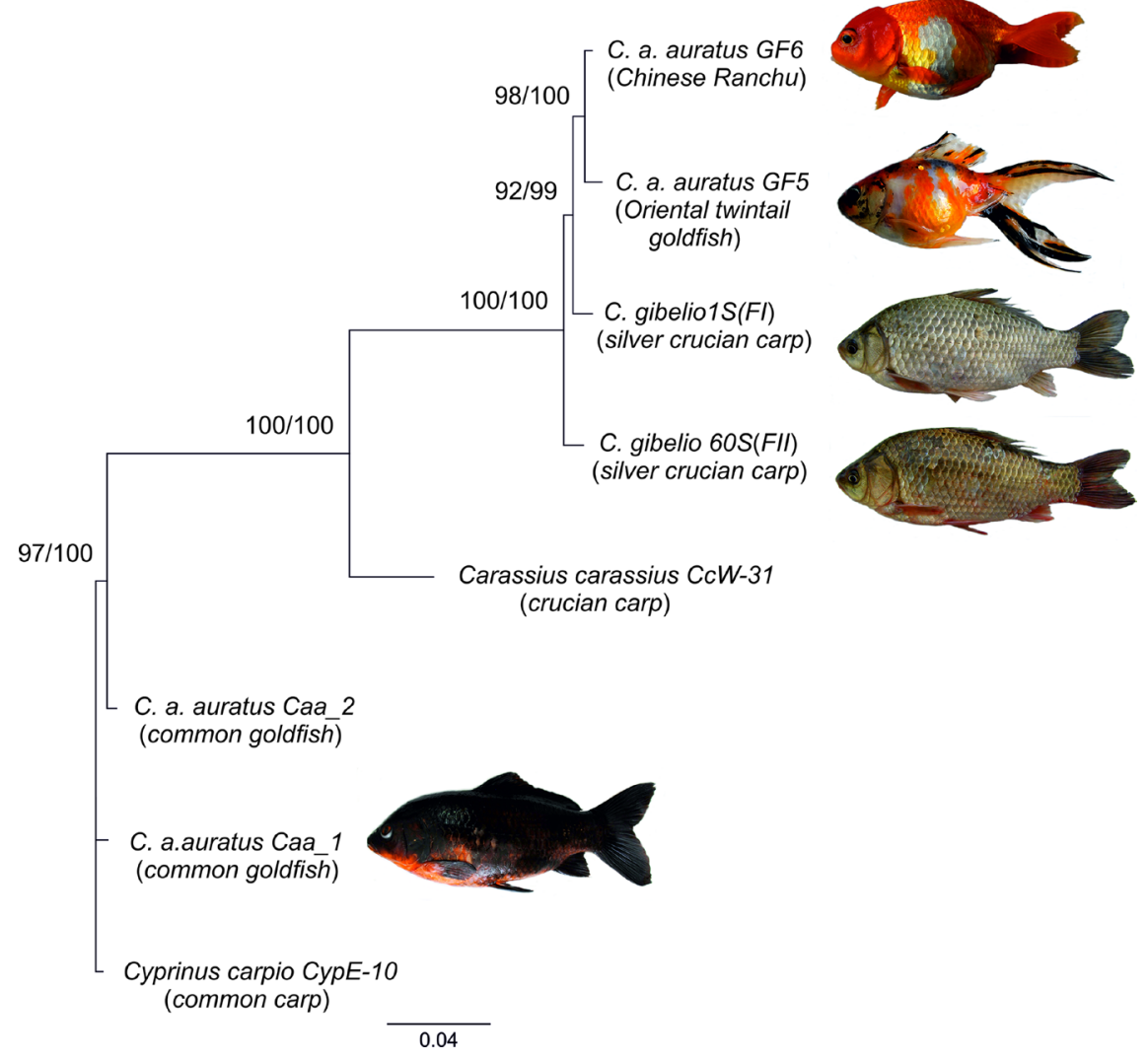

Figure 2. Consensus tree demonstrating ML and BI analysis of relationships of Carassius and Cyprinus carpio genus representatives generated from the 2474 bp combined nDNA (rps7, GH1 and $R h$ ) sequences. Numbers at the nodes of the branches with similar topology represent bootstrap support and posterior probabilities (PP, \%) for ML and BI trees, respectively.

proportions and color indicate that this form has developed by the type of the most primitive (simple) morphs of the goldfish $C$. a. auratus. The identity of nDNA sequences between this form of goldfishes and carp constituted $98.6 \%$ - 99.21\%, whereas the magnitude of genetic differences $(p)$ from DNA of other phenotypes of aquarium goldfishes did $14.39 \%$.

\section{Discussion}

Data of the present study, based upon the cyt $b$ fragment, agree to the most of previous studies of the $C$. auratus complex phylogeny, which used mitochondrial markers cyt $b$ and CR (Figure 1) [2] [5] [7] [8] [19] [20]. The clade C. a. auratus is formed by wild and various phenotypes of ornamental goldfishes that confirms the hypothesis on the origin of domesticated goldfish from wild ancestors C. a. auratus.

The results of the analysis of combined topologies of nDNA fragments, unlike the phylogram by mtDNA, showed that two individuals of ornamental common goldfish C. a. auratus combine with Cyprinus carpio (Figure 2) at a high degree of support. The high homology of each of the three nuclear (and combined fragments) with nuclear sequences of carp proves the origin of nuclear genes of this form from this species. At the same time, a phylogenetic analysis of mtDNA fragment in the same individuals reveals a close homology with the maternal line of C. a. auratus. Thus, there are grounds to suppose that this line of goldfishes originated as a re-

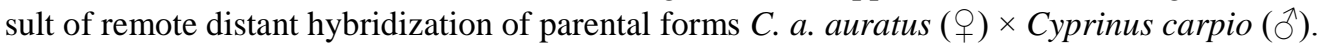

This stage of hybridization in the origin of ornamental goldfish, including that between C. carpio and C. auratus, was supposed earlier [21]. The probability of hybridization between C. auratus and C. carpio was shown both under experimental and natural conditions [22] [23]. The mechanism of integration of two genomes at remote hybridization is related to peculiarities of reproduction modes (bisexual reproduction and gynogenesis) and 
to production of different in ploidy egg cells by the goldfish C. a. auratus [24] [25]. The probability of formation of diploid hybrid forms is exemplified also by back-crossing and gynogenesis of hybrid females $\mathrm{F}_{1} C$. $a$. auratus $($ ㅇ $) \times$ C. carpio "Koi" (ð) with a male "Koi” carp [26]. The recent studies showed that diverse hybrid variants of bisexual and fertile goldfishes can be obtained by combining the natural androgenesis and gynogenesis of hybrids C. auratus (red var.) $(+$ ) $) \times$ C. carpio $(\widehat{0})[21]$.

The data obtained by us may be explained in two ways. First, the emergence of the "common form" of goldfish as a result of remote distant hybridization took place repeatedly. The directed or spontaneous remote hybridization of $C$. auratus $\times$ Cyprinus carpio makes transfer of nDNA from one species to another possible. Since the probability of interspecific hybridization at artificial breeding of representatives of the order Cypriniformes is high, hybrid forms may represent complex clones of polyphyletic origin as a consequence of multiple hybridizations. The earlier detected monophyly of the most diverse forms of goldfishes $C$. auratus from various regions of their habitat by cyt $b$ (mtDNA) may reflect only their matrilineal relationships within the $C$. auratus complex [2].

The other explanation of our data can rest upon the fact that hybridization and selection became multidirectional after the single event of hybridization C. auratus $\times$ Cyprinus carpio and the beginning of selection of ornamental forms. In one case, back crosses could be predominantly with the carp Cyprinus carpio that resulted in a substantial enrichment of nDNA of the goldfish hybrid form with the genome of common carp. In the other case, back crosses of the hybrid form were mostly with C. auratus; then the genome of these more recent forms of ornamental goldfish proved to be enriched in nDNA of $C$. auratus.

In our case, the shares of nuclear genes of $C$. $a$. auratus and Cyprinus carpio cannot be estimated through analysis of only three genes, neither in cryptic morphotypes of common goldfish nor, probably, in other forms, taking into account the monophyly of the origin of goldfish's ornamental forms by mtDNA. The lack of typical morphological characters of carps serves the evidence that some portion of their nuclear genes was lost or substituted by genes of $C$. a. auratus. Thus, obtained data show that there was a stage of remote hybridization during the formation of ornamental forms of goldfish, and the multidirectional selection resulted in polyphely by nuclear genes, but not by mtDNA. To confirm these data, an analysis of nDNA of a common goldfish from other collections is needed.

If our results are proved, we should not rule out errors in identification of the studied species, such as hybrid and "pure" goldfishes similar in their external characters and separate fragments of mtDNA, which potentially can be used for selective breeding or as model objects for laboratory-based research. Taking into account the high adaptability to environmental conditions, selection of desired characters in hybrid goldfishes may cause formation of new artificial populations or phenotypes with a higher genetic variability in aquaculture. For this reason, traditional approaches to identification of fish species, based on morphological characters and certain fragments of mtDNA cannot be always effective in studying the biodiversity of certain groups of aquarium fishes and in confirmation of validity of morphologically similar species.

\section{Conclusion}

Analysis of mtDNA showed that all forms of ornamental goldfish had a monophyletic origin from Chinese goldfish C. a. auratus. The analysis showed that three nuclear genes (rps7, GH1 and $R h$ ) in the two forms of ornamental goldfish (Oriental twintail goldfish and Chinese Ranchu) were almost identical C. a. auratus genes. At the same time all three genes in another form of goldfish (common goldfish) were highly homologous to carp Cyprinus carpio nuclear genes. The obtained data suggested that in the history of ornamental goldfish breeding occurred the stage of distant hybridization between goldfish and common carp. Subsequently, the nuclear genomes of some ornamental forms could be enriched by goldfish genes or common carp genes as a result of multidirectional selection of ornamental goldfish various forms.

\section{Acknowledgements}

The study was supported by the Grant of the Russian Science Foundation (\#14-50-00034).

\section{References}

[1] Balon, E.K. (2004) About the Oldest Domesticates among Fishes. Journal of Fish Biology, 65, 1-27. 
http://dx.doi.org/10.1111/j.0022-1112.2004.00563.x

[2] Rylkova, K., Kalous, L., Slechtova, S. and Bohlen, J. (2010) Many Branches, One Root: First Evidence for a Monophyly of the Morphologically Highly Diverse Goldfish. Aquaculture, 302, 36-41. http://dx.doi.org/10.1016/j.aquaculture.2010.02.003

[3] Wang, C.Y. (1985) The Origin of the Goldfish. Bulletin of Biology, 12, 11-12.

[4] Chen, I.S. and Fang, L.-S. (1999) The Freshwater and Estuarine Fishes of Taiwan. National Museum of Marine Biology and Aquarium, Pingtung.

[5] Gao, Y., Wang, S.Y., Luo, J., Murphy, R.W., Du, R., Wu, S.F., Zhu, C.L., Li, Y., Poyarkov, A.D., Nguyen, S.N., Luan, P.T. and Zhang, Y.P. (2012) Quaternary Palaeo Environmental Oscillations Drove the Evolution of the Eurasian Carassius auratus Complex (Cypriniformes, Cyprinidae). Journal of Biogeography, 39, 2264-2278. http://dx.doi.org/10.1111/j.1365-2699.2012.02755.x

[6] Chen, S.C. (1956) A History of the Domestication and the Factors of the Varietal Formation of the Common Goldfish, Carassius auratus. Scientia Sinica, 5, 287-321.

[7] Komiyama, T., Kobayashi, H., Tateno, Y., Inoko, H., Gojobori, T. and Ikeo, K. (2009) An Evolutionary Origin and Selection Process of Goldfish. Gene, 430, 5-11. http://dx.doi.org/10.1016/j.gene.2008.10.019

[8] Wang, S.-Y., Luo, J., Murphy, R.W., Wu, S.-F., Zhu, C.-L., Gao, Y. and Zhang, Y.-P. (2013) Origin of Chinese Goldfish and Sequential Loss of Genetic Diversity Accompanies New Breeds. PLoS ONE, 8, e59571. http://dx.doi.org/10.1371/journal.pone.0059571

[9] Sambrook, J., Fritsch, E.F. and Maniatis, T. (1989) Molecular Cloning: A Laboratory Manual. 2nd Edition, Cold Spring Harbor Laboratory, Cold Spring Harbor.

[10] Sevilla, R.G., Diez, A., Noren, M., Mouchel, O., Jerome, M., Verrez-Bagnis, V., Van Pelt, H., Favre-Krey, L. and Bautista, J.M. (2007) Primers and Polymerase Chain Reaction Conditions for DNA Barcoding Teleost Fish Based on the Mitochondrial Cytochrome b and Nuclear Rhodopsin Genes. Molecular Ecology Notes, 7, 730-734. http://dx.doi.org/10.1111/j.1471-8286.2007.01863.x

[11] Chow, S. and Hazama, K. (1998) Universal PCR Primers for S7 Ribosomal Protein Gene Introns in Fish. Molecular Ecology, 7, 1255-1256.

[12] Chen, W.-J., Bonillo, C. and Lecointre, G. (2003) Repeatability of Clades as a Criterion of Reliability: A Case Study for Molecular Phylogeny of Acanthomorpha (Teleostei) with Larger Number of Taxa. Molecular Phylogenetics and Evolution, 26, 262-288. http://dx.doi.org/10.1016/S1055-7903(02)00371-8

[13] Okonechnikov, K., Golosova, O., Fursov, M. and the UGENE Team (2012) Unipro UGENE: A Unified Bioinformatics Toolkit. Bioinformatics, 28, 1166-1167. http://dx.doi.org/10.1093/bioinformatics/bts091

[14] Tamura, K., Peterson, D., Peterson, N., Stecher, G., Nei, M. and Kumar, S. (2011) MEGA5: Molecular Evolutionary Genetics Analysis Using Maximum Likelihood, Evolutionary Distance, and Maximum Parsimony Methods. Molecular Biology and Evolution, 28, 2731-2739. http://dx.doi.org/10.1093/molbev/msr121

[15] Swofford, D.L. (2002) PAUP*: Phylogenetic Analysis Using Parsinomy (and Other Methods), Beta Version 10. Sinauer Associates, Sunderland.

[16] Huelsenbeck, J.P. and Ronquist, F. (2001) MRBAYES: Bayesian Inference of Phylogenetic Trees. Bioinformatics, 17, 754-755. http://dx.doi.org/10.1093/bioinformatics/17.8.754

[17] Posada, D. (2008) jModelTest: Phylogenetic Model Averaging. Molecular Biology and Evolution, 25, 1253-1256. http://dx.doi.org/10.1093/molbev/msn083

[18] Apalikova, O.V., Podlesnykh, A.V., Kukhlevsky, A.D., Guohua, S. and Brykov, V.A. (2011) Phylogenetic Relationships of Silver Crucian Carp Carassius auratus gibelio, C. auratus cuvieri, Crucian Carp Carassius carassius, and Common Carp Cyprinus carpio as Inferred from Mitochondrial DNA Variation. Russian Journal of Genetics, 47, 322331. http://dx.doi.org/10.1134/S1022795411020025

[19] Podlesnykh, A.V., Apalikova, O.V. and Brykov, V.A. (2012) Phylogenetic Relationships of Silver Crucian Carp in Carassius auratus Complex Based on mtDNA Analysis. Russian Journal of Genetics, 48, 1207-1217. http://dx.doi.org/10.1134/S1022795412120113

[20] Kalous, L., Rylková, K., Bohlen, J., Šanda, R. and Petrtýl, M. (2013) New mtDNA Data Reveal a Wide Distribution of the Japanese Ginbuna Carassius langsdorfii in Europe. Journal of Fish Biology, 82, 703-707. http://dx.doi.org/10.1111/j.1095-8649.2012.03492.x

[21] Wang, J., Liu, S., Xiao, J., Tao, M., Zhang, C., Luo, K. and Liu, Y. (2014) Evidence for the Evolutionary Origin of Goldfish Derived from the Distant Crossing of Red Crucian Carp $\times$ Common Carp. BMC Genetics, 15, 33. http://dx.doi.org/10.1186/1471-2156-15-33

[22] Liu, S.J. (2010) Distant Hybridization Leads to Different Ploidy Fishes. Science China Life Sciences, 53, 416-425. 
http://dx.doi.org/10.1007/s11427-010-0057-9

[23] Haynes, G.D., Gongora, J., Gilligan, D.M., Grewe, P., Moran, C. and Nicholas, F.W. (2012) Cryptic Hybridization and Introgression between Invasive Cyprinid Species Cyprinus carpio and Carassius auratus in Australia: Implications for Invasive Species Management. Animal Conservation, 15, 83-94. http://dx.doi.org/10.1111/j.1469-1795.2011.00490.X

[24] Liu, S.J., Sun, Y.D., Liu, K.K. and Liu, Y. (2006) Evidence of Different Ploidy Eggs Produced by Diploid $F_{2}$ Hybrids of Carassius auratus (ㅇ) $\times$ Cyprinus carpio (đ) $)$. Acta Genetica Sinica, 3, 304-311. http://dx.doi.org/10.1016/S0379-4172(06)60055-3

[25] Xiao, J., Zou, T., Chen, Y., Chen, L., Liu, S., Tao, M., Zhang, C., Zhao, R., Zhou, Y., Long, Y., You, C., Yan, J. and Liu, Y. (2011) Coexistence of Diploid, Triploid and Tetraploid Crucian Carp (Carassius auratus) in Natural Waters. BMC Genetics, 12, 20. http://dx.doi.org/10.1186/1471-2156-12-20

[26] Gomelsky, B., Schneider, K.J. and Plouffe, D.A. (2012) Koi × Goldfish Hybrid Females Produce Triploid Progeny When Backcrossed to Koi Males. North American Journal of Aquaculture, 74, 449-452.

http://dx.doi.org/10.1080/15222055.2012.676014 